\begin{tabular}{|c|c|c|}
\hline $\bar{J}$ & International Journal of Current Research in & \\
\hline & Biosciences and Plant Biology & $\div 37^{\circ}$ \\
\hline $\begin{array}{l}\text { EXCELLENT } \\
\text { PUBLISHERS } \\
\end{array}$ & $\begin{array}{c}\text { ISSN: 2349-8080 (Online) • Volume } 3 \bullet \text { Number } 5 \text { (May-2016) } \\
\text { Journal homepage: www.ijcrbp.com }\end{array}$ & \\
\hline
\end{tabular}

Original Research Article

doi: http://dx.doi.org/10.20546/ijerbp.2016.305.003

\title{
Stimulation of Hypericin Induction in Calli Cultures of Hypericum sinaicum (L.)
}

\author{
Heba D. Khlifa ${ }^{*}$, Ibrahim A. Ibrahim², M. Bekhit ${ }^{2}$, S. A. Bekheet ${ }^{1}$, H. M. El-Shabrawi ${ }^{1}$, \\ M. Szkop ${ }^{3}$ and H. S. Taha ${ }^{1 *}$
}

${ }^{1}$ Plant Biotechnology Department, National Research Centre (NRC), Dokki, Cairo, Egypt, P.O.12622

${ }^{2}$ Plant Biotechnology Department, Genetic Engineering Institute (GEBRI), University of Sadat City, Egypt

3Biochemistry Department, Faculty of Agriculture and Biology, Warsaw University of Life Sciences (SGGW), Poland

*Corresponding authors.

\begin{tabular}{|c|c|}
\hline Abstract & Article Info \\
\hline \multirow{3}{*}{$\begin{array}{l}\text { Sufficient and promising protocol for enhancement and production of hypericin in calli } \\
\text { cultures of Hypericum sinaicum was established. The highest value of calli cultures was } \\
\text { produced from nodal segment and root explants respectively. MS-medium supplemented } \\
\text { with } 3 \mathrm{mg} / \mathrm{l} \text { of } 2,4-\mathrm{D} \text { gave the best results of calli production under dark condition. } \\
\text { However, the lowest calli frequency }(28 \text { and } 20 \% \text { ) and fresh weights }(1.4 \text { and } 1.0 \mathrm{~g} / \mathrm{Jar} \text { ) } \\
\text { were estimated with nodal and root explants cultured on MS medium supplemented with } \\
0.25 \mathrm{mg} / \mathrm{l} 2,4-\mathrm{D}+0.25 \mathrm{mg} / \mathrm{lDZ} \text { under light condition. Calli growth dynamics were } \\
\text { investigated during five weeks of cultivation. Total hypericin produced by calli cultures } \\
\text { derived from nodal segment and root explant were evaluated using HPLC. }\end{array}$} & $\begin{array}{l}\text { Accepted: } 11 \text { April } 2016 \\
\text { Available Online: 06 May } 2016\end{array}$ \\
\hline & Keywords \\
\hline & $\begin{array}{l}\text { Calli } \\
\text { Growth dynamic } \\
\text { Hypericin } \\
\text { Hypericum sinaicum }\end{array}$ \\
\hline
\end{tabular}

Abbreviations: BA: N6-Benzyladenine; B5: Gamborg medium; 2, 4-D: 2,4-Dichlorophenoxyacetic acid; HPLC: High performance liquid chromatography; Kin: Kinetin; LS: Linsmaire and Skoog medium; MS: Murashige and Skoog medium; NAA: Naphthalene acetic acid; H. sinaicum: Hypericum sinaicum.

\section{Introduction}

Plants are essential to humanity for food, environmental intensification and personal fulfillment. Plants are also the foundations of healthy ecosystems ranging from the Arctic to the tropics. Propagation of plants holds tremendous potential for the production of high-quality plant-based medicines (Murch et al., 2000). The genus Hypericum belongs to the Hypericeae family which encompasses approximately 460 species accommodate in 36 sections throughout the world (Robson, 2006). The genus Hypericum includes both annual and perennial herbaceous plants, as well as woody, shrubs and small trees. The genus is of great economical and medicinal importance for containing of phytochemical constituents (Messina, 2006). Hypericum species carry secretory structures in above-ground organs (Soelberg et al., 2007), which are sites of synthesis and accumulation of biologically active substances (Ciccarelli et al., 2001; Onelli et al., 2002), primarily hypericin, pseudohypericin and their derivates protohypericin and protopseudohypericin (Bombardelli and Morazzoni, 1995). Hypericin and pseudohypericin, which are the basic chemicals of Hypericum extracts, are formed in sepals, petals, and stamens of Hypericum species (Zobayed et al., 2006), and these compounds have photodynamic, antiviral, antibacterial, antidepressant and antitumoral activities (Agostinis et al., 2002; Guedes and Eriksson, 2005).

$H$. sinaicum is one of the endemic species in Sant Katherin Protectorate South Sinai, Egypt (Khafagi and Omar, 2012). The importance of this species as a phytopharmaceutical, especially hypericin is a substance 
isolated from Hypericum spp. Hypericin belongs to group of compounds known as napthodianthrones. Hypericin is a secondary plant metabolite of Hypericum and the amount of hypericin strongly depend upon the source of the plant material (Wagner and Bladt, 1994).

Over the last decades, plant cell and tissue cultures represent a promising and a unique source for producing plant-derived medicinal metabolites under controlled culture conditions for decades (Jacqueline et al., 1999). In addition, compounds from tissue cultures are more easily purified because of the simple extraction processes used and the absence of contaminants such as pigments, thus consequently, reducing the production and processing costs (Bourgaud et al., 2001). Callus consist of an amorphous mass of loosely arranged thin walled parenchyma cell arising from the proliferating cell of the parent tissue frequently, as a result of wounding a callus is formed at the cut end of a stem or root. As well as callus tissues are an important factor in the establishment of cell cultures.

Production of secondary metabolites via plant cell and tissue cultures has various advantages such as obtaining desirable secondary metabolites and large scale production (De Boer et al., 2004). In recent years, plant cell culture techniques has been commonly applied to the production of many useful secondary metabolites, including pharmaceuticals, pigments, and other bioactive compounds (Verpoorte et al., 2002; Bourgaud et al., 2001). Several valuable studies have been performed on the production of useful secondary metabolites in plant cell cultures and organ cultures of some Hypericum species. The relationship between biosynthesis of hypericin compounds and in vitro development of differentiated structures in Hypericum plants has also been investigated (Coste et al., 2011; Palmer and Keller, 2011).

Although $H$. sinaicum is a very valuable medicinal plant but no method has been reported about in vitro study such as callus induction and in vitro propagation of this plant. Therefore, we conducted this study to assay the effects of plant growth regulators on callus induction and hypericin accumulation.

\section{Materials and methods}

\section{Plant materials}

Seeds of $H$. sinaicum for the present study were kindly provided by Dr. Hussein Taha, Plant Biotechnology Department National Research Centre, Cairo, Egypt.

\section{Methods}

\section{Initiation of sterilized $\boldsymbol{H}$. sinaicum seedlings}

H. sinaicum seeds were surface sterilized with $70 \%(\mathrm{v} / \mathrm{v})$ ethanol solution for $1 \mathrm{~min}$, followed by immersion in a $20 \%$ (v/v) commercial Sodium Hypochlorite (5.25 CL) for $10 \mathrm{~min}$., and rinsed three times with sterile distilled water. Sterile seeds were germinated and placed on the culture medium in jars $200 \mathrm{ml}$ contained $25 \mathrm{ml}$ each of three types of full and half strength of nutrient basal media containing, either MS salts (Murashig and Skoog, 1962), LS salts (Linsmaier and Skoog, 1965), or B5 salts (Gamborg et al., 1986), 0.7\% (w/v) agar, and $30 \mathrm{~g} / \mathrm{l}$ sucrose for 4 weeks. The $\mathrm{pH}$ of all types of nutrient media was adjusted to 5.8 before adding gelling agents. The media were autoclaved for $20 \mathrm{~min}$.

All cultures were incubated under $26 \pm 1{ }^{\circ} \mathrm{C}$ in a growth chamber with a daily16-h photoperiod under standard cool white fluorescent tubes at light intensity 20-25 $\mu \mathrm{mol}$ $\mathrm{m}^{-2} \mathrm{~s}^{-1}$. After 20-30 days, jars were checked and the germination percentages were scored. This experiment was consisted of 10 jars per type of nutrient medium as replicates.

\section{Establishment of $\boldsymbol{H}$. sinaicum $\mathbf{L}$. calli cultures}

Two types of explant nodal segment $(3 \mathrm{~mm})$ and root $(4 \mathrm{~mm})$ were excised from the previously in vitro germinated seedlings for callus induction. Explants were cultured on different types of culture media to test the effect of different exogenous growth regulators on callus induction. The following modified MS-media were used.

$$
\begin{aligned}
& \mathrm{MS}+1 \mathrm{mg} / \mathrm{l}(\mathrm{NAA})+1 \mathrm{mg} / \mathrm{l}(\mathrm{BA}) \\
& \mathrm{MS}+1 \mathrm{mg} / \mathrm{l}(\mathrm{NAA})+3 \mathrm{mg} / \mathrm{l}(\mathrm{BA}) \\
& \mathrm{MS}+1 \mathrm{mg} / \mathrm{l}(\mathrm{NAA})+5 \mathrm{mg} / \mathrm{l}(\mathrm{BA}) \\
& \mathrm{MS}+1 \mathrm{mg} / \mathrm{l}(2,4 \mathrm{D}) \\
& \mathrm{MS}+3 \mathrm{mg} / \mathrm{l}(2,4 \mathrm{D}) \\
& \mathrm{MS}+5 \mathrm{mg} / \mathrm{l}(2,4 \mathrm{D}) \\
& \mathrm{MS}+1 \mathrm{mg} / \mathrm{l}(2,4 \mathrm{D})+1 \mathrm{mg} / \mathrm{l}(\mathrm{kin}) \\
& \mathrm{MS}+1 \mathrm{mg} / \mathrm{l}(2,4 \mathrm{D})+3 \mathrm{mg} / \mathrm{l}(\mathrm{kin}) \\
& \mathrm{MS}+1 \mathrm{mg} / \mathrm{l}(2,4 \mathrm{D})+5 \mathrm{mg} / \mathrm{l}(\mathrm{kin}) \\
& \mathrm{MS}+0.25 \mathrm{mg} / \mathrm{l}(2,4 \mathrm{D})+0.25 \mathrm{mg} / \mathrm{l}(\mathrm{TDZ}) \\
& \mathrm{MS}+0.25 \mathrm{mg} / \mathrm{l}(2,4 \mathrm{D})+0.5 \mathrm{mg} / \mathrm{l}(\mathrm{TDZ}) \\
& \mathrm{MS}+0.25 \mathrm{mg} / \mathrm{l}(2,4 \mathrm{D})+0.75 \mathrm{mg} / \mathrm{l}(\mathrm{TDZ}) \\
& \mathrm{MS}+0.25 \mathrm{mg} / \mathrm{l}(2,4 \mathrm{D})+1 \mathrm{mg} / \mathrm{l}(\mathrm{TDZ})
\end{aligned}
$$


The replicates of each treatment consisted of five replicates. Cultures were incubated under $26 \pm 1^{\circ} \mathrm{C}$ in a growth chamber with a daily16-h photoperiod under standard cool white fluorescent tubes at light intensity $20-25 \mu \mathrm{mol} \mathrm{m}^{-2} \mathrm{~s}^{-1}$, and/ or in darkness for 4 weeks. Jars were checked regularly for callus induction. After 4 weeks the following parameters were recorded.

1- Percentage of explant forming callus.

2- Fresh weight (g/jar).

3- Callus figuration

The obtained calli cultures were sub-cultured on fresh modified MS media every month.

\section{Calli growth parameters}

Normal curve: According to Smith (2000) initiated calli cultures were divided to fragments $\sim 750 \mathrm{mg} / \mathrm{jar}(150 \mathrm{ml})$ and placed on a fresh nutrient medium modified with the best concentrations of growth regulators used for callus induction. This experiment was monitored for four weeks and incubated at $26 \pm 1^{\circ} \mathrm{C}$.

Growth rate $(\mathbf{G r})$ : According to Dung et al. (1981) fresh weights of calli cultures ( $\mathrm{g} /$ day) induced from nodal and root explants, were collected weekly intervals over the 5 weeks of cultivation. Four replicates of each explant were used and the growth rate calculated according the following equation:

$$
\text { (Ge - G0) / } 7
$$

Where,

$\mathrm{Ge}=$ the weight of callus $(\mathrm{g})$ at the end of $2^{\text {nd }}, 3^{\text {rd }}, 4^{\text {th }}$ or $5^{\text {th }}$ week;

$\mathrm{G} 0=$ the weight of callus at the end of previously week i.e., $1^{\text {st }}, 2^{\text {nd }}, 3^{\text {rd }}$ or $4 \mathrm{t}^{\mathrm{h}}$ week of cultivation.

Dry matter content (\%): The fresh weight (g) of different calli cultures were dried at $50^{\circ} \mathrm{C}$ for $48 \mathrm{hrs}$ and the dry matter content was estimated according the following equation:

Dry matter content $(\%)=($ Dry weight $/$ Fresh weight $) \times 100$

\section{Statistical analysis}

The obtained results were analyzed by ANOVA. The obtained results were statistically appraised according to Snedecor and Cochran (1980).

\section{Sample preparation for chemical analysis}

Derived calli from nodal and root explants were air dried on a filter paper to wipe away the agar and excised water. Moreover, in vitro germinated plants of $H$. sinaicum on MS medium free growth regulators were used as control treatment. All samples were dried in oven for 3 days at $50^{\circ} \mathrm{C}$ and grounded with a coffee grinder. Further, all dried samples were extracted and analyzed by HPLC to detect and determination of hypericin content.

\section{HPLC analysis}

This part of study was carried out in Polish Academy of Sciences (Department of Biochemistry- Faculty of Agriculture and Biology- Warsaw University of Life Sciences-SGGW) e-mail: kbioch@sggw.pl

The HPLC system was composed of a binary pump (Model 1525, Waters Corporation, Milford, MA, USA), a fluorimetric detector (Model 474, Waters; $\lambda \mathrm{ex}=236$ $\mathrm{nm} / \lambda \mathrm{em}=592 \mathrm{~nm}$ ), an autosampler (Model 717plus, Waters) and a personal computer with Breeze data acquisition and integration software (Waters). Chromatographic separations were performed at ambient temperature on a C8 column (Symmetry $4.6 \times 150 \mathrm{~mm}, 5$ $\mu \mathrm{m}$, Waters) fitted with a C8 guard column (Symmetry $3.9 \times 20 \mathrm{~mm}, 5 \mu \mathrm{m}$, Waters) using gradient eluents. Eluents A consisted of $60 \mathrm{mM}$ phosphate buffer $\mathrm{pH} 6.8$ and eluent B consisted of 80\%:20\% (v/v) acetonitrile: $\mathrm{H}_{2} \mathrm{O}$. The mobile phase started with eluent A: eluent B at $80 \%: 20 \%$, gradient programs of mobile phase (concentrations and run time) are shown in Table 1. The total run time was $100 \mathrm{~min}$. the flow rate of mobile phase was $1 \mathrm{ml} / \mathrm{min}$. the injection volumes were $20 \mu \mathrm{l}$.

Table 1. Gradient program of mobile phase.

\begin{tabular}{lll}
\hline Time (min.) & Eluent A (\%) $)^{*}$ & Eluent B (\%) ** \\
\hline 0 & 80 & 20 \\
18 & 0 & 100 \\
25 & 0 & 100 \\
27 & 80 & 20 \\
30 & 80 & 20 \\
\hline
\end{tabular}

+1 additional minute of column flushing with A: B 80\%: $20 \%$ before injection; Where: *Eluent A was $60 \mathrm{mM}$ phosphate buffer pH 6.8; **Eluent B was $80 \%$ acetonitrile: $20 \% \mathrm{H}_{2} \mathrm{O}$.

The relationship between the peak size and the amount of hypericin expressed as the sum of hypericin was tested. The linearity of a method was tested for the concentrations from $0.5 \mathrm{mg}$ of hypericin/ $\mathrm{ml}$. the equation of a straight line was $y=a x+b$, the regression coefficient $r=0.9995$ as shown in Figs. 1 and 2. 


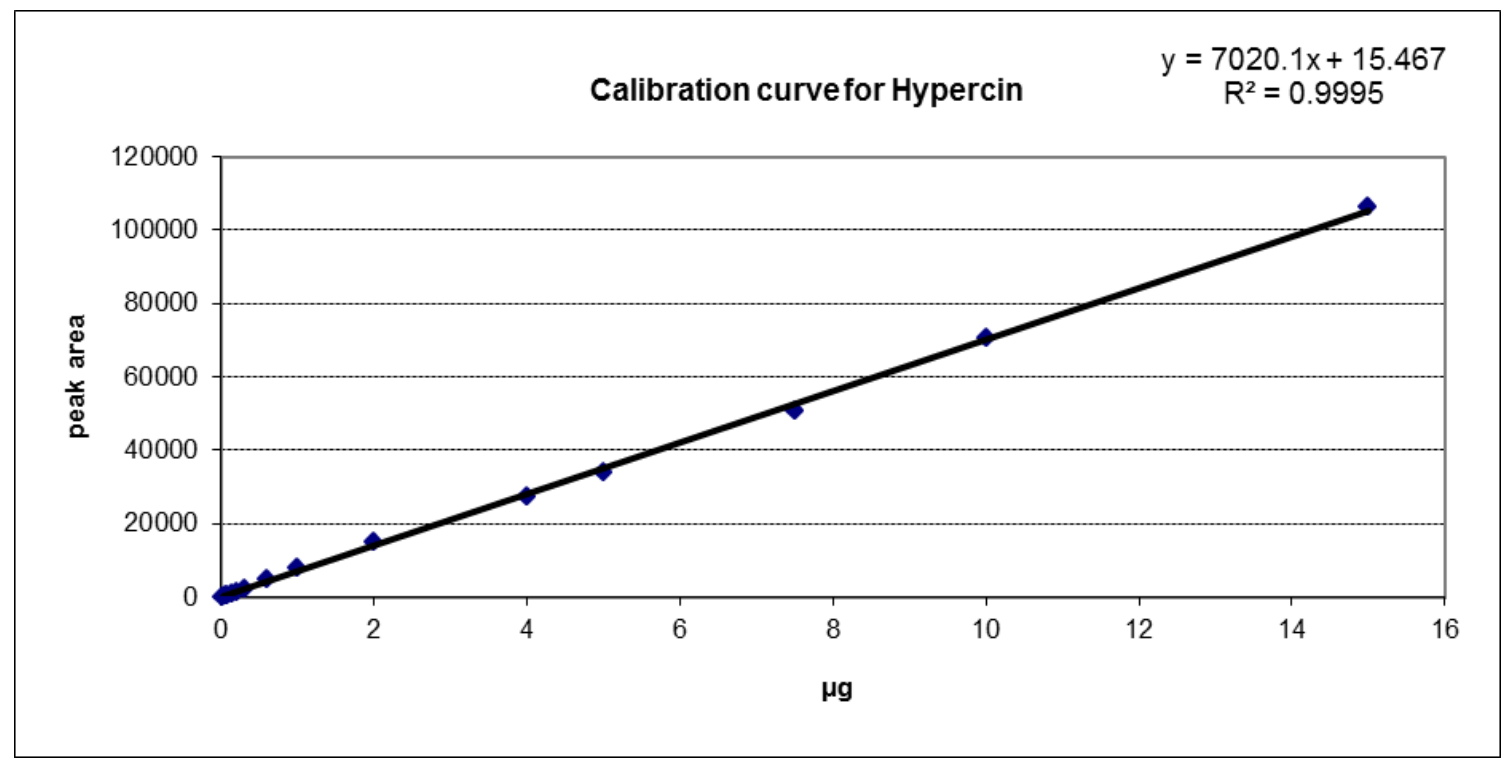

Fig. 1: Hypericin calibration curve.

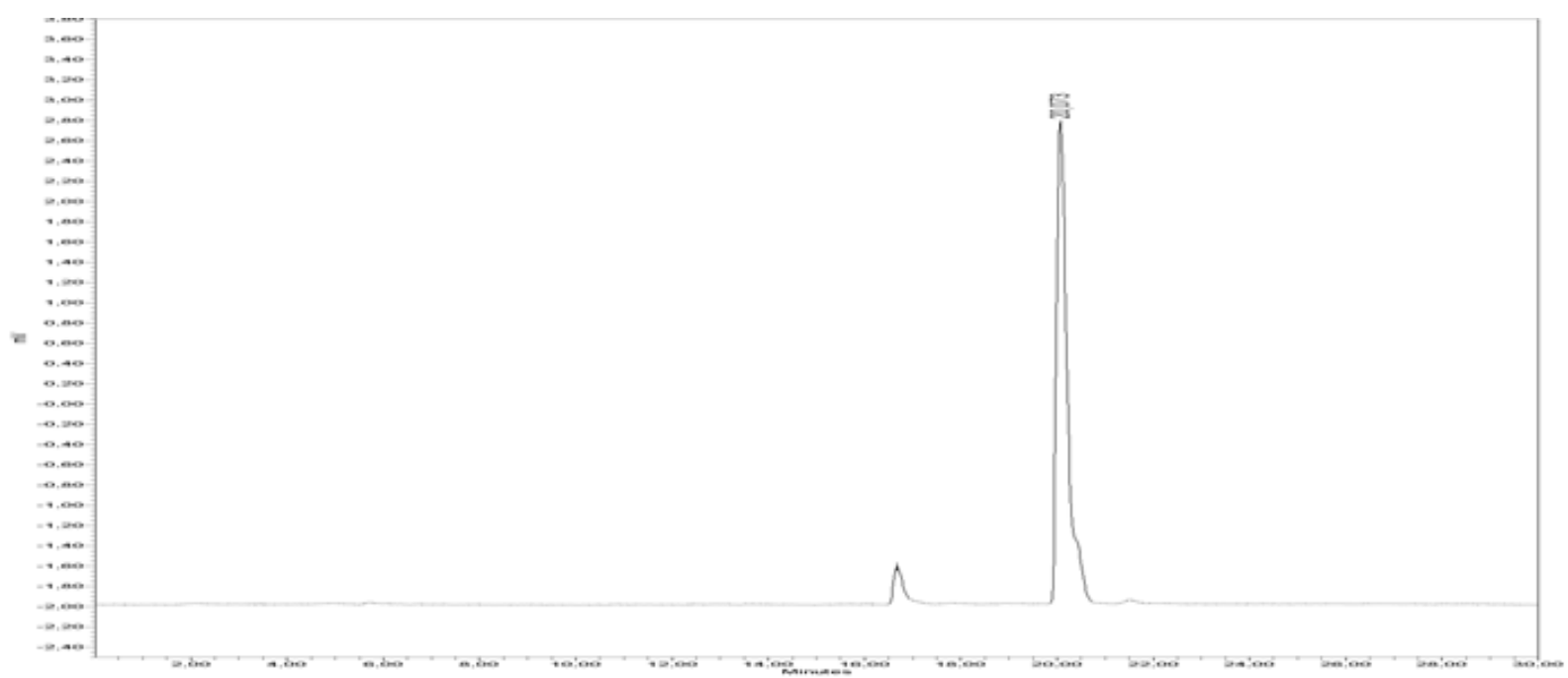

Fig. 2: Hypericin standard curve.

\section{Results}

\section{In-vitro seeds germination}

Full and half salt strengths of basal MS, LS and $\mathrm{B}_{5}$ nutrient media were investigated for $H$. sinaicum seeds germination under aseptic conditions. Cultures were incubated for 28 days at $26 \pm 1^{\circ} \mathrm{C}$ under light illumination (16/8hrs). Data tabulated in Table 2 showed that the highest percentages of seeds germination $(84 \%)$ was recorded with full salt strength of MS media compared other used nutrient media as shown in Fig. 3. However, the lowest percentage of seed germination $(20 \%)$ was obtained with half salt strength of $\mathrm{B}_{5}$ nutrient media.
Table 2. Effect of different nutrient media on percentage of in vitro H. sinaicum seeds germination.

\begin{tabular}{ll}
\hline Nutrient media & Germination (\%) \\
\hline MS & $84 \pm 0.33^{\mathrm{A}}$ \\
$1 / 2 \mathrm{MS}$ & $72 \pm 0.38^{\mathrm{AB}}$ \\
$\mathrm{LS}$ & $60 \pm 0.57^{\mathrm{B}}$ \\
$1 / 2 \mathrm{LS}$ & $40 \pm 0.64^{\mathrm{C}}$ \\
$\mathrm{B}_{5}$ & $64 \pm 0.45^{\mathrm{B}}$ \\
$1 / 2 \mathrm{~B}_{5}$ & $20 \pm 0.55^{\mathrm{D}}$ \\
$\mathrm{LSD}_{0.05}$ & 1.435 \\
\hline
\end{tabular}

Each value is the average of 10 replicates \pm Standard error; Average values within the column followed by the same letters are not significantly differed at $5 \%$ level. 


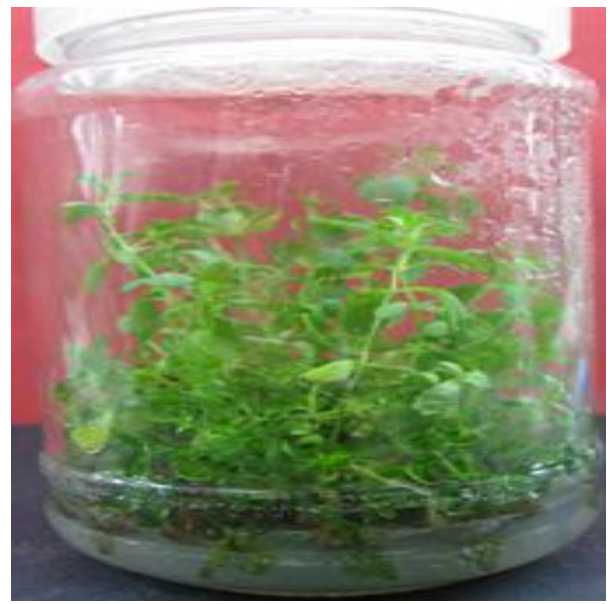

Fig. 3: $H$. sinaicum L. seeds germination on full salt strength of MS media.

\section{Optimization of in vitro culture conditions affecting on callus induction}

As shown in Table 3 the effect of MS medium supplemented with various growth regulators on callus induction from nodal and root explants were investigated. The obtained results clearly showed that, the highest frequencies of calli induction (96 and 72\%) were recorded with nodal and root explants (Figs. 4B and D) cultured on MS supplemented with $3 \mathrm{mg} / 1$ 2,4-D, and incubated under dark condition, respectively. However, those recorded 92 and 68\% under light condition (Figs. 4A and C). On same respect, the maximum values of calli fresh weight (4.8 and $3.6 \mathrm{~g} / \mathrm{jar}$ ) were recorded with nodal and root explants, respectively. MS medium fortified with $3 \mathrm{mg} / \mathrm{l}$ 2,4-D gave the best results of calli fresh weight compared other supplementations. In contrast, the lowest calli frequency formation (28 and 20\%) and fresh weights (1.4 and $1.0 \mathrm{~g} / \mathrm{Jar}$ ) were estimated with nodal and root explants cultured on MS medium supplemented with $0.25 \mathrm{mg} / 1$ 2,4$\mathrm{D}+0.25 \mathrm{mg} / \mathrm{l} \mathrm{TDZ}$ and incubated under light condition. However, those recorded 32 and 24 (\%) for calli frequency, and 1.6, $1.2 \mathrm{~g} / \mathrm{Jar}$ as fresh weights for nodal and root explants cultured on the same previously mentioned type of nutrient MS medium and incubated under dark condition, respectively. Regarding obtained calli phenotype it was recorded that, supplementation of MS medium with combinations of NAA and BA gave yellowish, green, friable and sometimes compact calli. Moreover, composition of MS medium with 2,4-D in combination with either Kin or TDZ produced yellow, friable and granular calli.

Table 3. Effects of MS medium supplemented with various $\mathrm{PGR}_{\mathrm{S}}$ at different concentrations on frequencies of calli induction and calli fresh weight of nodal and root explants of $H$. sinaicum incubated under light or dark condition at $26 \pm 1^{\circ} \mathrm{C}$.

\begin{tabular}{|c|c|c|c|c|c|c|c|c|c|}
\hline \multirow{2}{*}{\multicolumn{2}{|c|}{$\begin{array}{l}\text { MS media supplemented with growth } \\
\text { regulators (mg/l) }\end{array}$}} & \multicolumn{4}{|c|}{ Under light condition at $26 \pm 1^{\circ} \mathrm{C}$} & \multicolumn{4}{|c|}{ Under darkness conditions at $26 \pm 1^{\circ} \mathrm{C}$} \\
\hline & & \multicolumn{2}{|c|}{$\begin{array}{l}\text { Frequency of callus } \\
\text { induction }(\%)\end{array}$} & \multicolumn{2}{|c|}{$\begin{array}{l}\text { Callus fresh weight } \\
\text { (g/jar) }\end{array}$} & \multicolumn{2}{|c|}{$\begin{array}{l}\text { Frequency of callus } \\
\text { induction }(\%)\end{array}$} & \multicolumn{2}{|c|}{$\begin{array}{l}\text { Callus fresh weight } \\
\text { (g/jar) }\end{array}$} \\
\hline Auxin & Cytokinin & $\begin{array}{l}\text { Nodal } \\
\text { explant }\end{array}$ & $\begin{array}{l}\text { Root } \\
\text { Explant }\end{array}$ & $\begin{array}{l}\text { Nodal } \\
\text { explant }\end{array}$ & $\begin{array}{l}\text { Root } \\
\text { explant }\end{array}$ & $\begin{array}{l}\text { Nodal } \\
\text { explant }\end{array}$ & $\begin{array}{l}\text { Root } \\
\text { Explant }\end{array}$ & $\begin{array}{l}\text { Nodal } \\
\text { explant }\end{array}$ & $\begin{array}{l}\text { Root } \\
\text { Explant }\end{array}$ \\
\hline $1 \mathrm{mg} / \mathrm{l} \mathrm{NAA}$ & $1 \mathrm{mg} / \mathrm{l} \mathrm{BA}$ & 88 & 68 & $4.4 \pm 0.31$ & $3.4 \pm 0.31$ & 92 & 72 & $4.6 \pm 0.31$ & $3.6 \pm 0.31$ \\
\hline $1 \mathrm{mg} / \mathrm{l} \mathrm{NAA}$ & $3 \mathrm{mg} / \mathrm{l} \mathrm{BA}$ & 80 & 64 & $4 \pm 0.57$ & $3.2 \pm 0.48$ & 88 & 68 & $4.4 \pm 0.51$ & $3.4 \pm 0.51$ \\
\hline $1 \mathrm{mg} / 1(2,4 \mathrm{D})$ & 0 & 68 & 60 & $3.4 \pm 0.31$ & $3 \pm 0.40$ & 72 & 64 & $3.6 \pm 0.31$ & $3.2 \pm 0.25$ \\
\hline $3 \mathrm{mg} / \mathrm{l}(2,4 \mathrm{D})$ & 0 & 92 & 68 & $4.6 \pm 0.31$ & $3.4 \pm 0.31$ & 96 & 72 & $4.8 \pm 0.25$ & $3.6 \pm 0.31$ \\
\hline $5 \mathrm{mg} / \mathrm{l}(2,4 \mathrm{D})$ & 0 & 80 & 60 & $4 \pm 0.40$ & $3 \pm 0.40$ & 84 & 64 & $4.2 \pm 0.25$ & $3.2 \pm 0.25$ \\
\hline $1 \mathrm{mg} / \mathrm{l}(2,4 \mathrm{D})$ & 5 mg/l Kin & 48 & 36 & $2.4 \pm 0.65$ & $1.8 \pm 0.63$ & 52 & 40 & $2.6 \pm 0.51$ & $2 \pm 0.40$ \\
\hline $0.25 \mathrm{mg} / \mathrm{l}(2,4 \mathrm{D})$ & $0.25 \mathrm{mg} / \mathrm{l} \mathrm{TDZ}$ & 28 & 20 & $1.4 \pm 0.65$ & $1 \pm 0.40$ & 32 & 24 & $1.6 \pm 0.51$ & $1.2 \pm 0.48$ \\
\hline $0.25 \mathrm{mg} / 1(2,4 \mathrm{D})$ & $0.50 \mathrm{mg} / 1 \mathrm{TDZ}$ & 36 & 32 & $1.8 \pm 0.25$ & $1.6 \pm 0.31$ & 40 & 32 & $2 \pm 0.0$ & $1.6 \pm 0.31$ \\
\hline $0.25 \mathrm{mg} / \mathrm{l}(2,4 \mathrm{D})$ & $0.75 \mathrm{mg} / \mathrm{l} \mathrm{TDZ}$ & 48 & 32 & $2.4 \pm 0.77$ & $1.6 \pm 0.77$ & 52 & 36 & $2.6 \pm 0.65$ & $1.8 \pm 0.75$ \\
\hline $0.25 \mathrm{mg} / \mathrm{l}(2,4 \mathrm{D})$ & $1 \mathrm{mg} / \mathrm{l} \mathrm{TDZ}$ & 72 & 52 & $3.6 \pm 0.51$ & $2.6 \pm 0.31$ & 76 & 52 & $3.8 \pm 0.48$ & $2.6 \pm 0.31$ \\
\hline
\end{tabular}

Each value is the average of 5 replicates \pm standard error. 

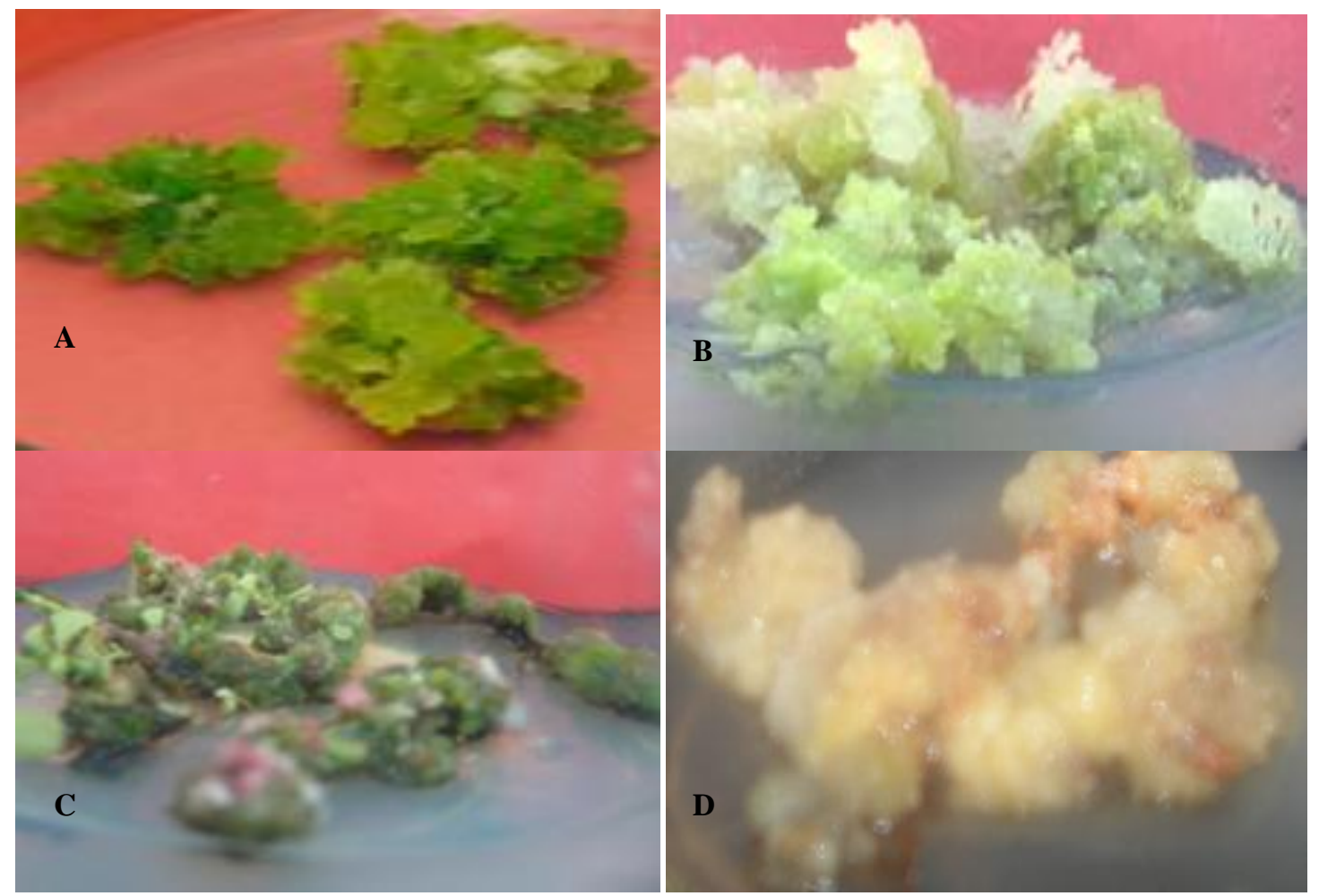

Fig. 4: Effect of MS media supplemented with 3mg/l 2,4D on calli induction from nodal explant (A and $\mathrm{B})$, root explant ( $\mathrm{C}$ and $\mathrm{D})$ of $H$. sinaicum incubated under light and dark conditions.

\section{Calli growth parameters}

The growth characteristics and pattern of calli derived from nodal and root explants of $H$. sinaicum growing in MS media containing $3 \mathrm{mg} / \mathrm{l}$ of $2,4 \mathrm{D}$ was investigated. Calli growth patterns were expressed as fresh weight $(\mathrm{g})$, dry weight $(\mathrm{g})$ and dry matter content (\%). The growth dynamics of the obtained different calli cultures were determined weekly for five weeks of cultivation. The obtained data clearly showed that the highest values of calli fresh weight 5.4 and 4.83 $(\mathrm{g} / \mathrm{Jar})$ were recorded at the end of the $5^{\text {th }}$ week of cultivation for nodal and root explants, respectively.

Regarding those dry weight and dry matter content values of the callus derived from different explants were calculated. The results clearly showed that the highest dry weights were obtained at the end of the $5^{\text {th }}$ week of cultivation as shown in Fig. 5A. Also, the maximum dry matter content $(82.2$ and $82 \%)$ was recorded with nodal and root explant, respectively at the end of the $5^{\text {th }}$ week of cultivation as shown in Fig. 5B. In addition, daily growth rates $(0.33$ and 0.18 $\mathrm{g} /$ day) were recorded at the end of the $3^{\text {rd }}$ week of cultivation for nodal and root explants, respectively.
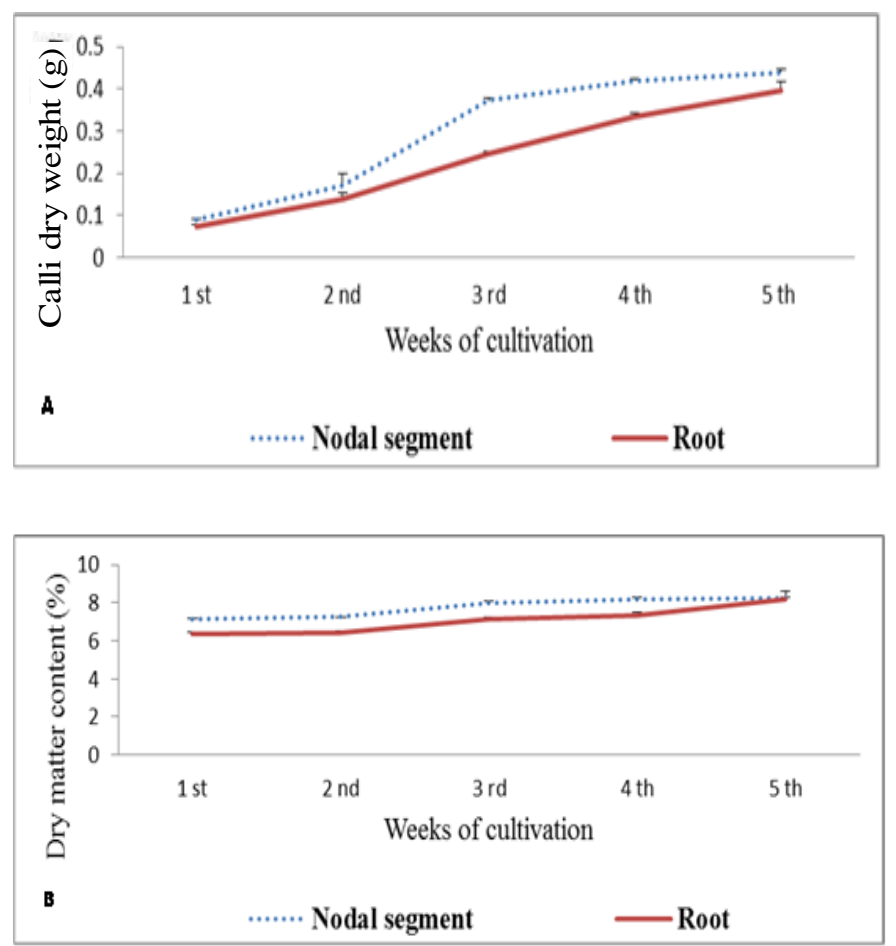

Fig. 5: Dry weight (A) and dry matter content\% (B) of calli derived from nodal and root explants of $H$. sinaicum during five weeks of cultivation. 


\section{Hypericin content ( $\mu \mathrm{g} / \mathrm{g}$ dry weight)}

Total hypericin content extracted from in vitro derived plantlets on free MS medium; calli cultures derived from either nodal or root explants cultured on MS medium supplement with 3mg/l 2,4D was determined and compared to hypericin standard curve (Fig. 2).
The data clearly revealed that the highest accumulation of hypericin contents $32.99 \mu \mathrm{g} / \mathrm{g}$ dry weights was recorded in in vitro plantlets grown on free full salt strength of MS medium (Fig. 6A), while calli cultures derived from nodal and root explants were recorded $21.09,7.23 \mu \mathrm{g} / \mathrm{g}$ dry weight, respectively (Fig. 6B and $\mathrm{C}$ ).
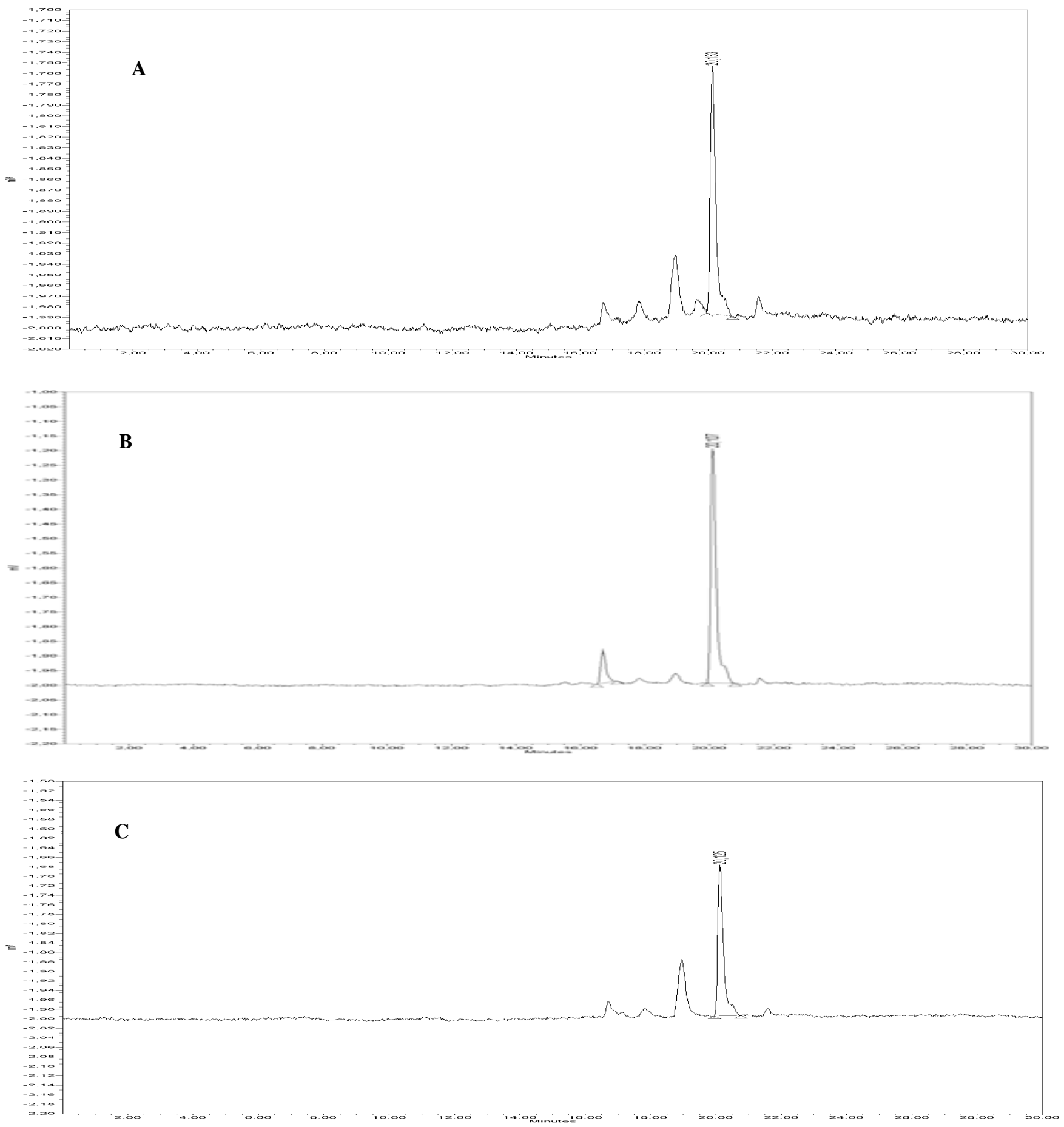

Fig. 6: HPLC peaks of hypericin extracted from; in vitro plantlets (control) (A); calli derived from nodal segment (B) and root explant $(\mathrm{C})$ of $H$. sinaicum. 


\section{Discussion}

Plant tissue culture, or the aseptic culture of cells, tissues, organs, and their components under defined physical and chemical conditions in vitro, is an important tool in both basic and applied studies as well as in commercial application (Thorpe, 1990). Different approaches have been taken to enhance yields of secondary metabolites. These include cell cloning and the repeated selection of high-yielding strains from heterogeneous cell populations (Dougall, 1987). Generalizations about plant growth regulators and their use in plant cell culture media summarized by George et al. (2008) who reported that, auxins promote both cell division and cell growth. The most important naturally occurring auxin is IAA (indole-3-acetic acid), but it is limited used because it is unstable to both heat and light. 2,4-Dichlorophenoxyacetic acid $(2,4-\mathrm{D})$ is the most commonly used auxin and is extremely effective in most circumstances.

The obtained results showed that, the highest frequencies of calli induction (96\%) were recorded with nodal explants grown in MS containing $3 \mathrm{mg} / \mathrm{l}$ 2,4-D, and incubated under dark condition. Pretto and Santarém (2000) reported that MS basal media containing BA in combination with 2,4-D showed the highest calli formation, while Walker et al. (2002) reported that BA in combination with 2,4-D was efficient for calli formation. Ayan et al. (2005) obtained that the highest frequency of callus induction from the leaf discs cultivated on the medium supplemented with of 2,4-D and kinetin.

According to previous reports, in combinations with 2,4-D and kinetin or BA proved to be effective plant growth regulators for callus induction and cell suspension cultures from $H$. perforatum. Regarding the stimulating effect of darkness on callus initiation and callus production, our results may support those of Yazaki and Okuda (1990) they found that highest callus initiation and mass callus production of $H$. perforatum was achieved when cultures were incubated under dark condition.

Also in our study, the obtained results showed that in vitro cultivation of nodal and root explants of $H$. sinaicum during 3 weeks was more economically and significantly for calli production. These results in close with Smith (2000) who reported that, the rate of growth of calli tissue parallels in many ways the sigmoid curve seen in population of single. There are usually five stages for callus growth rate; a lag phase in which cells prepare to divide, a period of exponential growth in which cell division is maximal, a period of linear growth in which division slows down and cells enlarge, a period of decelerating growth and stationary or no-growth period in which the number and size of cells is constant.

Hypericin content of calli derived from nodal segment cultured on MS medium containing 2,4-D was 21.09 $\mu \mathrm{g} / \mathrm{g}$ dry weight, while this rate was $7.23 \mu \mathrm{g} / \mathrm{g}$ dry weight in calli derived from root explant. Hypericin content of in vitro plantlets derived free MS medium was $32.99 \mu \mathrm{g} / \mathrm{g}$ dry. A similar study on hypericin content in calli cultures of $H$. triquetrifolium Turra was conducted by Oluk et al. (2010) they detected $0.048 \mathrm{mg} \mathrm{g}^{-1}$ amount of hypericin in calli of $H$. triquetrifolium. In another study, Santarem and Astarita (2003) reported that the level of hypericin in calli of $H$. perforatum was very low, representing only $0.11 \%$ of the amount found in the field-grown plants. Moreover, it has been reported that callus initiated from stamens of $H$. perforatum showed only traces of hypericin or pseudohypericin (Kirakosian et al., 2000). In addition, Pasqua et al. (2003) reported that although undifferantiated calli and suspension cultures in MS medium containing $1.105 \mathrm{mg} / \mathrm{l}$ 2,4-D, $0.215 \mathrm{mg} / \mathrm{l} \mathrm{Kin}$ and $0.186 \mathrm{mg} / \mathrm{l}$ NAA was not produce hypericin or pseudohypericin but calli with vegetative buds produced hypericin $(0.015 \%)$ and pseudohypericin $(0.050 \%)$.

\section{Conclusion}

In this study, we reported for the first time a protocol for the successful callus induction, in $H$. sinaicum which would provide more homogenous source of medicine. The frequency of callus induction from nodal explants described here was high enough to encourage us to carry out, regeneration culture, genetic transformation and cell suspension culture for improvement of secondary metabolites quality and quantity.

\section{Conflict of interest statement}

Authors declare that they have no conflict of interest.

\section{Funding}

This study was funded by Science Technology Development Fund (STDF), Egypt [short term fellowship (STF) number 6548]. 


\section{Acknowledgement}

This article is based on part of experiments from Ph.D. dissertation of the first author, Heba D. Khlifa. The author (Heba D. Khlifa) is grateful to Dr. H. S. Taha, Professor of Plant Biotechnology and Genetic Engineering Plant Biotechnology Department, Genetic Engineering Division, National Research Centre, Cairo, Egypt for his help to achieve this work.

\section{References}

Agostinis, P., Vantieghem, A., Merlevede, W., De Witte, P. A. M., 2002. Hypericin in cancer treatment: more light on the way. Int. J. Biochem. Cell Biol. 34, 221-241.

Ayan, A. K., Çırak, C., Kevseroğlu, K., Sökmen, A., 2005. Effects of explant types and different concentrations of sucrose and phytohormones on plant regeneration and hypericin content in Hypericum perforatum L. Turk. J. Agric. For. 29, 197-204.

Bombardelli, E., Morazzoni, P., 1995. Hypericum perforatum. Fitoterapia. 66, 43-68.

Bourgaud, F., Gravot, A., Milesi, S., 2001. Production of plant secondary metabolites: a historical perspective. Plant Sci. 161, 839-851.

Ciccarelli, D., Andreucci, A. C., Pagni, A. M., 2001. Translucent glands and secretory canals in Hypericum perforatum L. (Hyperiacaceae): morphological, anatomical and histochemical studies during the course of ontogenesis. Ann. Bot. 88, 637-644.

Coste, A., Vlase, L., Halmagyi, A., Deliu, C., Coldea, G. 2011. Effects of plant growth regulators and elicitors on production of secondary metabolites in shoot cultures of Hypericum hirsutum and Hypericum maculatum. Plant Cell Tiss. Organ Cult. 106, 279-288.

De Boer, B., Glickman, W., Saxena, P. K. 2004. Optimized system for biomass production, chemical characterization and evaluation of chemo-preventive properties of Scutellaria baicalensis Georgi. Plant Sci. 167,439-446.

Dougall, D.K., 1987. Primary metabolism and its regulation. In: Plant Tissue and Cell Culture (Eds.: Green, C.E., Somers. D.A., Hackett, W.P., Biesboer, D.D.). A. R. Liss, New York. pp.97-117.

Dung, N.N., Szoki, E., Verzar-Petri, G., 1981. The growth dynamics of callus tissue of root and leaf origin in Datura innoxia Mill. Acta Bot. Acad. Scient. Hung. 27(3/4), 325333.

Gamborg, O.L., Miller, R.A., Ojima, O., 1968. Nutrient requirements of suspension cultures of soybean root cell. Exp. Cell Res. 50, 151-158.

George, E. F., Hall, M. A., De Klerk, G., (Eds.), 2008. Plant Propagation by Tissue Culture. $3^{\text {rd }}$ Edn. pp.175-204.

Guedes, R. C., Eriksson, L. A., 2005. Theoretical study of hypericin. J. Photochem. Photobiol. A-Chem. 172, 293299.
Jacqueline, V.S., Sushi, K.J., Rijhwani, M., Vani, R.B., Ho, C.H., 1999. Quantification of Metabolic Fluxes for Metabolic Engineering of Plant Products, Plant Cell and Tissue Culture for the Production of Food Ingredients. (Eds.: Fu, T-J., Singh, G., Curtis, W.R.). Kluwer Academic/ Plenum Publishers, New York.

Khafagi, O., Omar, K., 2012. Geographical Attributes Analysis for Egyptian Hypericum sinaicum. Univ. J. Environ. Res. Technol. 2(6), 500-514.

Kirakosian, A. B., Vardapetyan, R. R., Charchoglyan A. G., 2000. The content of hypericin and pseudohypericin in cell cultures of Hypericum perforatum. Russ. J. Plant Physiol. 47, 270-273.

Linsmaier, E.M., Skoog, F., 1965. Organic growth factor requirements of tobacco tissue cultures. Physiol. Plant. 18, 100-127.

Messina, B. A. M., 2006. Herbal supplements: Facts and myths-talking to your patients about herbal supplements. J. Peri. Anesth. Nurs. 21, 268-278.

Murashig, T., Skoog, F., 1962. A revised medium for rapid growth and bioassay with tobacco tissue cultures. Physiol. Plant. 15, 473-497.

Murch, S.J., Krishna, R.S., Saxena, P.K., 2000. Tryptophan is a precursor for melatonin and serotonin biosynthesis in invitro regenerated St. John's wort (Hypericum perforatum L. cv. Anthos) plants. Plant Cell Rep. 19, 698-704.

Oluk, E. A., Orhan, S., Karakaş, Ö., Çakır, A., Gönüz, A., 2010. High efficiency indirect shoot regeneration and hypericin content in embriogenic callus of Hypericum triquetrifolium Turra. Afr. J. Biotechnol. 9, 2229-2233.

Onelli, E., Rivetta, A., Giorgi, A., Bignami, M., Cocucci, P. G., 2002. Ultrastructural studies on the developing secretory nodules of Hypericum perforatum. Flora. 197, 92-102.

Palmer, C. D., Keller, W. A. 2011. Plant regeneration from petal explants of Hypericum perforatum L. Plant Cell Tiss. Organ. Cult. 105, 129-134.

Pasqua, G., Pinarosa, A., Monacelli, B., Santamaria, A. R., Argentiere, M. P., 2003. Metabolites in cell suspension cultures, calli, and in vitro regenerated organs of Hypericum perforatum cv Topas. Plant Sci. 165, 977-982.

Pretto, F. R., Santarém, E. R., 2000. Callus formation and plant regeneration from Hypericum perforatum leaves. Plant Cell Tiss. Organ Cult. 62, 107-113.

Robson, N. K. B., 2006. Studies in the genus Hypericum L. (Clusiaceae). Section 9. Hypericum sensu lato (part 3): subsection 1. Hypericum series 2. Senanensia, subsection 2. Erecta and section 9b. Graveolentia. Syst. Biodivers. 4, 19-98.

Santarem, E. R., Astaritam, L. V., 2003. Multiple shoot formation in Hypericum perforatum and hypericin production. Brazilian J. Plant Physiol. 15, 43-47.

Smith, R.H. 2000. Callus induction. In: Plant Tissue Culture Techniques and Experiments. $2^{\text {nd }}$ Edn. Academic Press, San Diego, California. pp.98-103.

Snedecor, G.W., Cochran, W.G., 1980. Statistical Methods, $7^{\text {th }}$ Edn. Iowa State University Press, USA. 504p. 
Soelberg, J., Jørgensen, L.B., Jäger, A. K., 2007. Hyperforin accumulates in the translucent glands of Hypericum perforatum. Ann. Bot. 99, 1097-1100.

Thorpe, T.A., 1990. The current status of plant tissue culture. In: Plant Tissue Culture: Applications and Limitations (Eds.: Bhojwani, S.S.). Elsevier, Amsterdam. pp.1-33.

Verpoorte, R., Contin, A., Memelink, J., 2002. Biotechnology for the production of plant secondary metabolites. Phytochem. Rev. 1, 13-25.

Wagner, H., Bladt, S., 1994. Pharmaceutical quality of Hypericum extracts. J. Geriat. Psych. Neurol. 7, S65-S68.
Walker, T. S., Bais, H. P., Vivanco, J. M., 2002. Jasmonic acid-induced hypericin production in cell suspension cultures of Hypericum perforatum L. (St. John's wort). Phytochem. 60, 289-293

Yazaki, K., Okuda, T., 1990. Procyanidins in callus and multiple shoot cultures of Hypericum erectum. Planta Med. 56, 490-491.

Zobayed, S. M. A., Afreen, F., Goto, E., Kozai. T., 2006. Plant environment interactions: accumulation of hypericin in dark. 804.

\section{How to cite this article:}

Khlifa, H. D., Ibrahim, I. A., Bekhit, M., Bekheet, S. A., El-Shabrawi, H.M., Szkop, M., Taha, H. S., 2016. Stimulation of hypericin induction in calli cultures of Hypericum sinaicum (L.). Int. J. Curr.

Res. Biosci. Plant Biol. 3(5), 11-20. doi: http://dx.doi.org/10.20546/ijcrbp.2016.305.003 